\title{
Additív gyártás alkalmazása a kovácsszerszám-javításban
}

\section{Application of Additive Manufacturing for the Repair of Forging Dies}

\author{
Uzonyi Sándor
}

Flexman Robotics Kft. Budapest, Magyarország, us@flexmanrobotics.hu

\begin{abstract}
In this paper the investigated conditions and possibilities of repairing forging dies with high pre-cision robotic MAG welding are presented. Different welding wire electrodes were examined and compared by their processability. Productivity, process stability, slag and fume formation were in the focus of investigation. Metallographic tests were carried out to validate the compliance of welded layers. Based on the performance of the wire electrodes, recommendations have been elaborated for the procedure specification and also for further investigation. Some robot cell lay-outs have been designed adapting to the special working environment and requirements of the welding procedure.
\end{abstract}

Keywords: additive manufacturing, wire arc additive manufacturing, robotic welding, hardfacing.

\section{Összefoglalás}

A dolgozat célja kovácsszerszámok javító-felrakó hegesztésének robotizálására alkalmas hegesztőhuzal kiválasztása, a hozzá tartozó hegesztéstechnológia kidolgozása és validálása volt. A munka során többféle huzalelektródát hasonlítottam össze. Az összehasonlítás középpontjában a feldolgozhatóságot befolyásoló tulajdonságok voltak, mint a termelékenység, az ívstabilitás, a salak- és füstképződés. Az elkészült kemény rétegeket metallográfiai módszerekkel vizsgáltam, hogy kötésminőség szempontjából is megfelelőek-e. A munka során gyüjtött tapasztalatok figyelembevétele mellett a konkrét alkalmazást megvalósító robotcella kialakítására is dolgoztam ki koncepciókat.

Kulcsszavak: additív gyártás, huzalelektródás ivhegesztéses additív gyártás, robotosított hegesztés, javítóhegesztés.

\section{Bevezetés}

\subsection{Célkitüzés}

A Flexman Robotics Kft. ügyfélkörében érdeklődés merült fel a melegalakító szerszámacélok javítóhegesztésének robotosítására, a hegesztőanyag-felvitel pontosságának növelése érdekében, ezzel csökkentve a hegesztési és megmunkálási időt, valamint az ehhez kapcsolódó költségeket. A kutatómunka célja erre alkalmas hegesztőanyag, ehhez tartozó hegesztéstechnológia és robotrendszer tervezése volt. Ehhez kísérleteket végeztem a javítani kívánt szerszámacél hegeszt- hetőségének értékelésére, melyek közben értékeltem a vizsgált hegesztőanyagok felhasználhatóságát és a technológia megbízhatóságát leginkább befolyásoló tényezőket, majd az elkészült kemény rétegeket metallográfiai vizsgálatoknak vetettem alá, a felhasználás során alkalmazott technológia validálása érdekében.

\subsection{A felrakóhegesztés fő jellemzői}

A felrakóhegesztés széles körben alkalmazott eljárás karbantartási, javítási munkák során, illetve olyan termékek előállításakor, melyek felülete lényegesen eltérő tulajdonságú kell hogy 
legyen a keresztmetszet belsejéhez képest. Felrakóhegesztés alkalmazásakor jellemzően az egész felületet egy vagy több rétegben hegesztik fel, illetve anyaghiány pótlásakor, annak környezetét részben vagy egészben eltávolítva, az eredeti folytonossági hiánynál sokkal nagyobb részt hegesztenek fel. A precizitás növeléséhez az ilyen tevékenységet végző vállalatnak szoros gazdasági érdeke fűződik. A felrakóhegesztés hegesztőanyagai igen drágák, illetve a felhegesztett többletanyagot utólag forgácsolással el kell távolítani, ami szintén nagyon költséges, mivel ezek az anyagok általában nehezen forgácsolhatók [1].

A hagyományos felrakóhegesztés és az additív gyártás között a pontosság teremt kapcsolatot, amit szerzőtársaimmal korábban részletesen elemeztünk [2]. A huzalelektródás ívhegesztéssel végzett additív gyártás (angolul WAAM, wire and arc additive manufacturing) területén lényeges előrelépések történtek az elmúlt években. Egyre több gyakorlati alkalmazás születik, és a nagy pontosságú szerszámjavítással foglalkozó cégek száma is gyarapodik [3-5].

\subsection{A hegeszthetőség vizsgálata}

A kopott, elhasználódott szerszámok szakszerű javítása jelentős haszonnal járhat, ugyanis az eredetinek megfelelő minőség elérésén túl, a hegesztőanyag és technológia körültekintő kiválasztásával, az eredetinél hosszabb élettartam is lehetséges. Egy szerszámot akár többször is lehet javítani, így a jól megtervezett javító-felrakó hegesztési technológia igen költséghatékony [6].

A szerszámacélok, hegesztésüket tekintve, két nagy csoportba oszthatók: erősen ötvözött, valamint közepesen ötvözött és ötvözetlen szerszámacélok. Jelentős részük az edzési hőmérsékletről körülbelül 30 min alatt az előmelegítési hőmérsékletre hűtve hosszú ideig lágy, ausztenites marad. Ebben a hőmérséklet-tartományban maradva hosszú ideig dolgozhatunk repedésveszély nélkül. Erősen vagy gyengén ötvözött szerszámacélok hegesztésére általánosan elterjedt és nagy biztonsággal alkalmazható módszer ez, azonban nem mindig engedhető meg ilyen nagymértékű előmelegítés [1]. Az általam vizsgált, EN ISO 4957 szerinti jelöléssel: 55NiCrMoV7 (rövid jel: 1.2714), szerszámacélból készült szerszám sem melegíthető elő ebbe a tartományba. Az előmelegítés és a hozzá tartozó fajlagos hőbevitel meghatározására számos módszert dolgoztak már ki, de ezek a nagy szénegyenérték miatt nem, vagy csak különleges megfontolásokkal alkalmazhatók. Ezek közül többet is megvizsgáltam, itt csak kettőt mutatok be.

\subsubsection{A Kasuya-Yurioka-módszer}

Egy lehetséges közelítés a nagy széntartalmú acélok 50\% martenzitet eredményező lehülési idejének meghatározásához tartozó számítási módszer. Ezt a módszert T. Kasuya és N. Yurioka pontosította [7] a CEH Harden-féle szén-egyenérték [8] felhasználásával:

$$
\begin{aligned}
& T_{\mathbf{5 0}}=\left(T_{m} \cdot T_{b}\right)^{0,5}=\exp \left(5,3 C E_{H}+3,1 C E_{I I I}-2,03\right) \\
& C E_{I I}=C+\frac{S i}{24}+\frac{M n}{6}+\frac{C u}{15}+\frac{N i}{12}+\frac{C r}{8}+\frac{M o}{4}+\Delta H \\
& C_{I I I}=C+\frac{M n}{3,6}+\frac{C u}{20}+\frac{N i}{9}+\frac{C r}{5}+\frac{M o}{4} \\
& T_{m}=\exp \left(10,6 C E_{H}-4,8\right) \\
& T_{b}=\exp \left(6,2 C E_{I I I}-0,74\right)
\end{aligned}
$$

ahol

$T_{50}-$ az 50\% martenzittartalomhoz tartozó lehülési idő,

$T_{m}$ - a 100\% martenzittartalomhoz tartozó lehűlési idő,

$T_{b}$ - a 0\% martenzittartalomhoz tartozó lehűlési idő,

$C E_{H}$ - a Harden-féle karbonegyenérték,

$C E_{I I I}$ - a varratfém szilárdságának becsléshez tartozó, Yurioka-féle karbonegyenérték.

Fontos megjegyezni, hogy ez csak közelítésre alkalmas, mivel a $C E_{H}$ csak 0,3\% széntartalomig értelmezhető, e fölött az összefüggés a karbon-egyenérték és a széntartalom között nem lineáris. Ezt az összefüggést alkalmazva az 1.2741 anyaghoz tartozó kritikus lehülési idő 4-226 perc az összetételtől függően [7]. Ez a nagy intervallum jól mutatja a számítás pontosságának viszonylagosságát. Más közelítőmódszerek, ahol az 1.2741 szénegyenértéke kívül esett az értelmezési tartományon, hasonló eredményekre vezetnek [8, 9].

\subsubsection{Béres módszere erősen ötvözött acélok- hoz}

Leghelyesebben akkor járunk el, ha az alapanyag CCT-diagramjából indulunk ki, és a hegesztést az úgynevezett bénites előmelegítéssel végezzük. Ilyenkor az előmelegítés hőmérséklete a bénites átalakulási görbe orrpontja, az előmelegítést pedig lassan végezzük.

Ez alapján (1. ábra) az előmelegítés hőmérsékletét $400-450{ }^{\circ} \mathrm{C}$-ban határoztam meg, és a próbatesteket kemencével együtt hütöttem [10].

\subsection{A felhasznált hegesztőanyagok}

A kísérletekhez négyféle hegesztőanyagot használtam, ezek összetételükben és feldolgozási tulajdonságaikban is jelentősen eltértek. Minden 


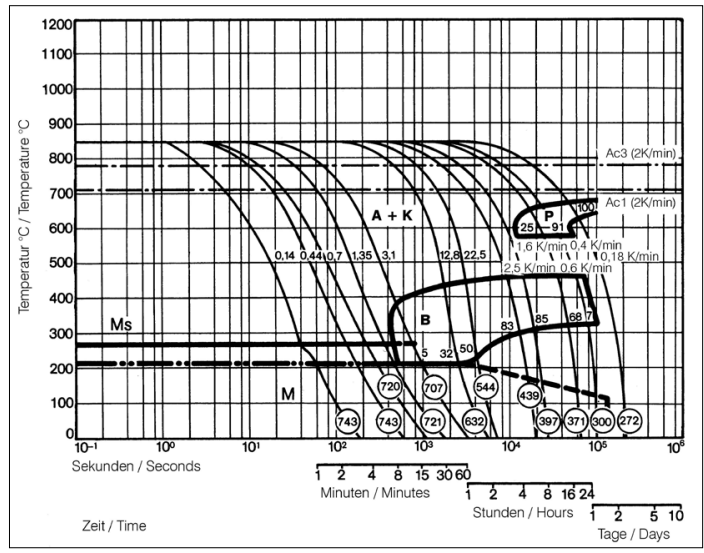

1. ábra. Az 1.2741 szerszámacél CCT-diagramjának releváns része (függőleges tengely: hömérséklet $\left({ }^{\circ} \mathrm{C}\right)$, vízszintes tengely: idő (s) [10]

huzal portöltetű volt, és a robotosított hegesztési folyamatoknál megszokotthoz képest (1 mm) nagyobb átmérőjű, a főbb adatokat az 1. táblázat tartalmazza.

A hegesztési technológia kidolgozása során a gyártók által megadott technológiai ablak ellenőrzésére és felülvizsgálatára is szükség volt.

1. táblázat. A hegesztőanyagok összesítése

\begin{tabular}{|c|c|c|c|}
\hline Huzal & Alapfém & Fő ötvözők & Átmérő \\
\hline $\mathrm{H} 1$ & $\mathrm{Fe}$ & Cr-Mo-C & $1,2 \mathrm{~mm}$ \\
\hline $\mathrm{H} 2$ & $\mathrm{Fe}$ & Mo-Cr-C & $1,2 \mathrm{~mm}$ \\
\hline $\mathrm{H} 3$ & $\mathrm{Fe}$ & Nb-Cr-C & $1,6 \mathrm{~mm}$ \\
\hline $\mathrm{H} 4$ & $\mathrm{Ni}$ & $\mathrm{Cr}-\mathrm{Mo}-\mathrm{W}$ & $1,6 \mathrm{~mm}$ \\
\hline
\end{tabular}

\section{A hegesztési kísérletek}

A huzalok vizsgálatához $100 \times 100 \times 250 \mathrm{~mm}$ befoglalóméretű próbatestekre két rétegben $6 \mathrm{~mm}$ vastag réteget hegesztettem fel Yaskawa EA1400as robottal, M21-es gázkeverékkel. Eközben vizsgáltam a feldolgozhatóságot, és később ezekből a próbatestekből munkáltam ki mintákat a metallográfiai vizsgálatokhoz.

\subsection{A feldolgozhatóság értékelése}

A feldolgozhatóság értékelése során több olyan szempont merül fel, melyeket nehéz kvantitatív módon értékelni. Az általam fontosnak tartott sajátosságokat pontozásos módszerrel értékeltem és táblázatos formában összegeztem. A pontozás során a hegesztőanyagok egyes tulajdonságait egytől négyig pontoztam, ahol az 1 a legrosszabb, a 4 a legjobb pontszám. A vizsgált tulajdonságok és azok értékelésének szempontjai az alábbiak, a kiértékelést a 2. táblázat összegzi:
- Ívstabilitás (I.): sikerült-e a gyártó által megadott áramerősség-feszültség ablakban olyan beállításokat találni, amelyek mellett stabil, jól fókuszált, irányítható ív jön létre?

- Fröcskölés (II.): a legstabilabb ív mellett kialakuló fröcskölés mértéke és a szétrepülő cseppek mérete. A minél kevesebb és minél kisebb méretű fröcskölés a kedvező.

- Varratalak (III.): mekkora a varratdudor peremszöge, fennáll-e folytonossági hiány kialakulásának veszélye a következő sor hegesztése során, mennyire lesz egyenletes vagy hullámos a felület hegesztés után? A széles és kis peremszögü varratok a kívánatosak.

- Termelékenység (IV.): a próbatest hegesztésével eltöltött idő. A minél termelékenyebb eljárást tekintem kedvezőbbnek.

- Salak (V.): a hegesztést követően kialakuló salak mennyisége és tapadása a felülethez. A minél könnyebben eltávolítható, vékony, könnyen felolvasztható salakréteg kedvezőbb.

- Füst (VI.): a kevesebb füst- és koromképződéssel lehegeszthető huzal kedvezőbb.

\section{2. táblázat. A hegesztőanyagok összehasonlítása}

\begin{tabular}{|c|c|c|c|c|c|c|c|}
\hline Jel & I. & II. & III. & IV. & V. & VI. & $\sum$ \\
\hline H1 & 2 & 3 & 2 & 2 & 3 & 3 & 15 \\
\hline H2 & 1 & 2 & 3 & 3 & 4 & 3 & 15 \\
\hline H3 & 4 & 4 & 4 & 4 & 1 & 1 & 18 \\
\hline H4 & 4 & 3 & 4 & 3 & 4 & 2 & 20 \\
\hline
\end{tabular}

\subsection{A technológia megfelelőségének igazo- lása}

A próbatesteket először vizuális vizsgálatnak (VT) vetettem alá, majd a lehűlést követően, amennyiben lehetséges volt, folyadékbehatolásos vizsgálatnak is (PT). Azokat a próbatesteket, melyek nem feleltek meg ezeken a vizsgálatokon, már nem vetettem alá a mikro- és makroszerkezeti, valamint a keménységvizsgálatnak (HV). Az eredményeket a 3 . táblázat foglalja össze.

3. táblázat. $A$ kötések vizsgálatának összesitése; $O K=$ megfelelö, $N O=$ nem megfelelö, - = nem vizsgált (a próbatest jele azonos a készítéséhez használt huzaléval)

\begin{tabular}{|c|c|c|c|c|c|c|}
\hline Jel & VT & PT & Mikro & Makro & HV & \\
\hline H1 & OK & OK & OK & OK & OK & OK \\
\hline H2 & NO & OK & - & - & - & NO \\
\hline H3 & - & - & OK & NO & OK & OK \\
\hline H4 & NO & NO & - & - & - & NO \\
\hline
\end{tabular}


A H2 hegesztőanyag esetében jelentős áramerősség-ingadozás lépett fel a hegesztés során, ami nagyméretű összeolvadási hiányokat okozott. Az ettől nem érintett varratrészek repedésmentesek voltak.

A 4. hegesztőanyag esetében a beállítások során még megfelelően működő huzal jelentős porozitású varratfémet produkált. A H3 hegesztőanyag esetében a salakréteg olyan vastag és jól tapadó volt, hogy eltávolítása nem volt lehetséges, továbbá a rétegek között nagyméretü salakzárványok maradtak vissza. A H1 huzal mikroszerkezeti felvételein egyenletes eloszlású mikrosalakzárványok figyelhetők meg; ezek a működést nem befolyásolják jelentősen, méretük és mértékük elfogadható.

\section{A robotcella kialakítása}

A lehetséges robotcella-változatok kialakítása során az alábbi szempontokat kellett figyelembe venni:

- Elérés: a robotnak úgy kell elérni a munkadarabot, hogy hegesztés közben ne alakuljon ki szinguláris karhelyzet.

- Hozzáférés: a robot és a hegesztőpisztoly közösen határozza meg. A belső kábelezésű kialakítás előnyös.

- Hőterhelés: a nagy előmelegítési hőmérséklet miatt kulcsfontosságú kérdés. A melegnek jobban ellenálló vagy kisebb hőterhelésű kialakítást kell előnyben részesíteni.

Minden robotcellát két munkahelyesnek terveztem. Ez lehetővé teszi, hogy a darabok előkészítését a hegesztés helyén végezzék.

\subsection{Nagy karkinyúlású robot}

A robotkar jelentős része a hegesztés helyétől távol helyezkedik el, ezért a munkadarab sugárzó hője kevésbé terheli, illetve nagyméretű szerszámokat is elér (2. ábra). Ennek a kialakításnak hátránya, hogy a robotkar egy általános hegesztőrobothoz képest kevésbé univerzális, így ha a már meglévő feladat megszűnik, nehezebb újat találni. A külső kábelezésű hegesztőpisztoly nem biztosít olyan jó hozzáférést, mint az integrált kábelezésű robotokra szerelhetők.

\subsection{Utazópályára szerelt robot}

Az YR MH2010 egy hosszabbított munkaterü, belső kábelezésű hegesztőrobot, bármilyen hegesztési feladat ellátására megfelelő (3. ábra). TSL 1000 utazópályával a robot munkatere nagymértékben megnövelhető, az elérés nemcsak mennyiségében, de minőségében is javul, mert könnyebben elkerülhetők a szinguláris karhelyzetek.

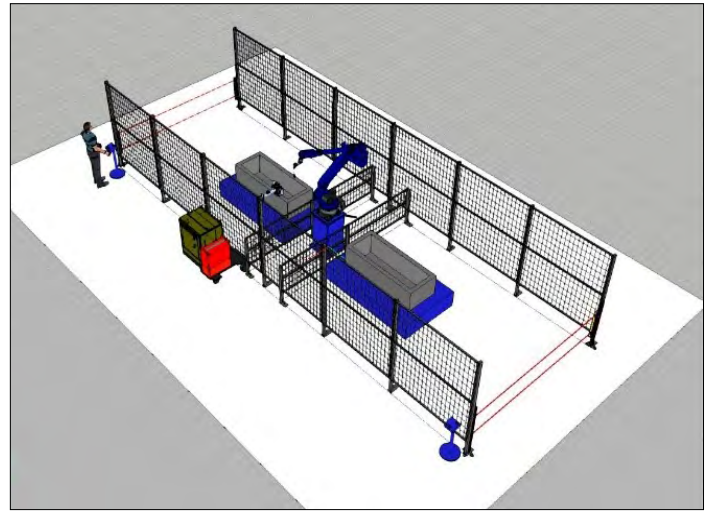

2. ábra. Robotcella nagy kinyúlású robotkarral

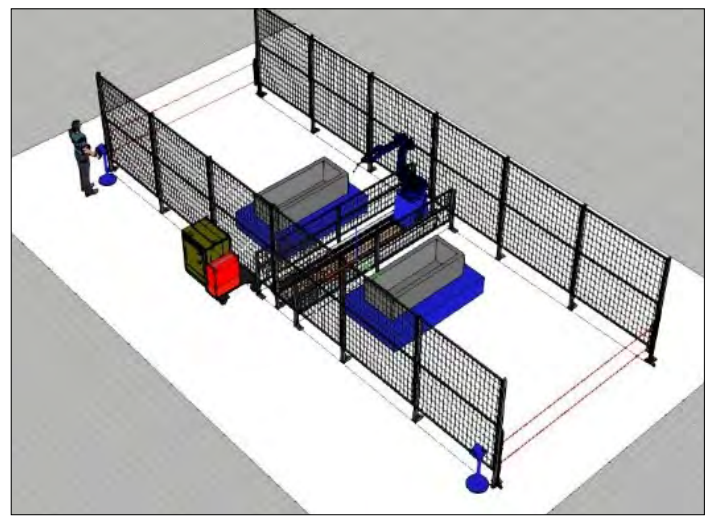

3. ábra. Robotcella utazópályás robottal

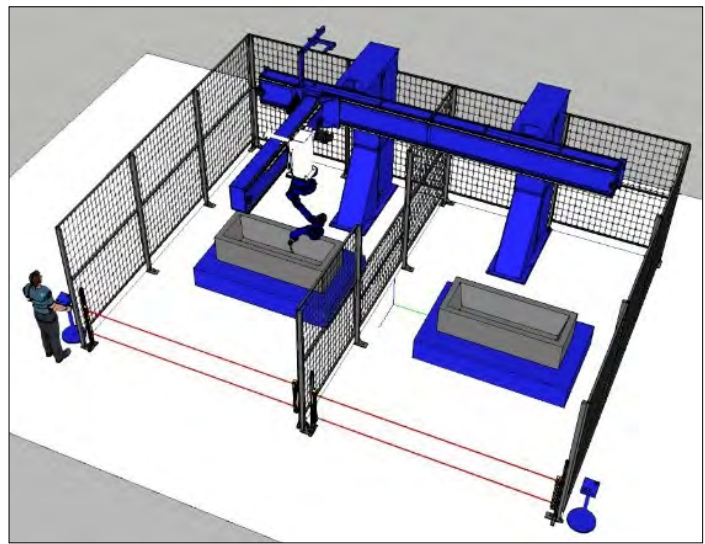

4. ábra. Kéttengelyes, felső utazópályára szerelt robotkar

\subsection{Felsőpályás robot}

A kéttengelyes, felső utazópályára szerelt Gantry-robotkar legnagyobb előnye, hogy munkaterülete nagyon nagy, ennek köszönhetően egy nagyméretű kovácsszerszám minden pontját ugyanazzal a magabiztossággal éri el (4. ábra). 


\section{4. Összefoglalás}

Az optimális hegesztőanyagot csak üzemi koptatóvizsgálatok segítségével választhatjuk ki. Erre a H1 hegesztőanyag megkötések nélkül bocsátható. A H3 hegesztőanyag kiváló feldolgozhatósága ellenére valószínüleg nem alkalmas a feladatra, ha a salakzárványok kialakulását nem sikerül további kísérletek során megnyugtatóan megszüntetni. A H2 huzal során tapasztalt előtolási problémák recés görgővel és nagyobb szorítóerővel megszüntethetők, további vizsgálatok javasoltak. A H4 huzalból új adagot beszerezve a vizsgálatokat érdemes megismételni.

A robotcella kialakítását a megrendelővel közösen kell meghatározni, mivel az üzemi adottságok és az anyagi lehetőségek felülírhatják az egyéb megfontolásokat. Robotprogramozás és elérés szempontjából a felső utazópályás cella a legjobb kialakítás, de a robot hőterhelése is ebben az esetben a legnagyobb; ezért vizsgálni kell, hogy a berendezés milyen kiegészítő védelem mellett képes ezt elviselni.

\section{Szakirodalmi hivatkozások}

[1] Béres L: Javitó- és felrakóhegesztések. In: Hegesztési zsebkönyv. (Szerk.: Gáti J.). Cokom Mérnökiroda Kft., Miskolc, 2003. 539-557.

[2] Uzonyi S., Asztalos L., Farkas A., Dobránszky J.: Additív hegesztéses gyártás jelene és jövője. Hegesztéstechnika, 28. (2017) 89-92.

[3] Ding D. et al.: Wire-feed additive manufacturing of metal components: technologies, developments and future interests. The International Journal of Advanced Manufacturing Technology, 81/1-4. (2015) 465-481.

https://doi.org/10.1007/s00170-015-7077-3
[4] Wang F. et al.: Microstructure and Mechanical Properties of Wire and Arc Additive Manufactured Ti-6Al-4V. Metallurgical and Materials Transactions A, 44/2. (2013) 968-977. https://doi.org/10.1007/s11661-012-1444-6

[5] Ding D. et al.: A multi-bead overlapping model for robotic wire and arc additive manufacturing (WAAM). Robotics and Computer-Integrated Manufacturing, 31. (2015) 101-110. https://doi.org/10.1016/j.rcim.2014.08.008

[6] Ali Y. et al.: Wire arc additive manufacturing of hot work tool steel with CMT process. Journal of Materials Processing Technology, 269. (2019) 109-116.

https://doi.org/10.1016/j.jmatprotec.2019.01.034

[7] Kasuya T., Yurioka N.: Determination of Necessary Preheat Temperature to Avoid Cold Cracking under Varying Ambient Temperature. ISIJ International, 35/10. (1995) 1183-1189. https://doi.org/10.2355/isijinternational.35.1183

[8] Bauer F., Béres L., Buray Z., Szita L.: A legfeljebb közepesen ötvözött edzhető acélok. In: A hegesztés anyagismerete és a hegesztéstechnológia alapjai. Budapesti Műszaki Egyetem Mérnöki Továbbképző Intézet, Budapest, 1995. 54-64.

[9] Béres L.: Determination of an optimized Interpass Temperature for the Welding of Martensitic Stainless Steels. The International Journal for the Joining of Materials, 9/1. (1997) 16-19.

[10] Bauer F., Béres L., Buray Z., Szita L.: Erősen ötvözött edzhető acélok előmelegitési hőmérsékletének meghatározása. In: A hegesztés anyagismerete és a hegesztéstechnológia alapjai. Budapesti Műszaki Egyetem Mérnöki Továbbképző Intézet, Budapest, 1995. 64-68. 